This is a self-archived version of an original article. This version may differ from the original in pagination and typographic details.

Author(s): Virtanen, Pekka

Title: Making conservation sustainable under unfavourable conditions : the case of Chimanimani National Reserve, Mozambique

Year: 2020

Version: Accepted version (Final draft)

Copyright: @ 2019 Informa UK Limited, trading as Taylor \& Francis Group

Rights: In Copyright

Rights url: http://rightsstatements.org/page/InC/1.0/?language=en

Please cite the original version:

Virtanen, P. (2020). Making conservation sustainable under unfavourable conditions : the case of Chimanimani National Reserve, Mozambique. Development in Practice, 30(3), 320-331.

https://doi.org/10.1080/09614524.2019.1682521 


\title{
Making conservation sustainable under unfavourable conditions: the case of Chimanimani NR, Mozambique
}

Pekka Virtanen

Department of Social sciences and Philosophy

University of Jyväskylä, Finland

E-mail: pekka.k.virtanen@jyu.fi

Kentän koodi muuttunut

Development in Practice, Received 30 Nov 2018, Accepted 19 Jun 2019, Published online: 29 Oct 2019 (https://doi.org/10.1080/09614524.2019.1682521)

\begin{abstract}
Based on a case study from the Chimanimani National Reserve in Mozambique, the article analyses to what extent different types of operational practices can contribute to the sustainability of PAs in relatively unfavourable external conditions. While current conservation policies highlight community participation and market-based approaches, the same 'best practices' are not equally valid under different conditions. Where unfavourable natural conditions, lack of infrastructure, difficult access and political instability limit the potential for upmarket ecotourism, the actors should focus on community empowerment, diversification of livelihoods, and building joint conservation ideology, on which they have direct influence through the operational practices.
\end{abstract}

Keywords: Africa, Nature conservation, Ecotourism, Markets, Mozambique, Operational practice, Protected areas

\section{INTRODUCTION}

Since the late 1980s, nature conservation policy has sought to combine conservation with economic development and human rights protection. Recognising that establishing protected areas (PAs) imposes costs on the local population, who must therefore be integrated into the process and compensated through adequate benefits, the credo of the policy is that benefits can be ensured through private sector participation and market forces (Child 2011). However, some early critics noted that economic benefits from PAs tend to go mostly to national and international actors, while the costs fall mainly on local communities (Wells 1992). The hyped 'win-win' outcome is rather unlikely unless operational conditions, including a legal and policy framework to secure local community rights, are favourable. In Africa, only some PAs have natural conditions considered ideal for upmarket ecotourism and safari hunting, which are perceived as prime sources of PA income. In addition, lack of infrastructure, difficult access and political instability often aggravate market potential (Adams and Hulme 2001; Krüger 2005; Wells 1992), while shrinking public funding can cover only a fraction of the conservation budget (Emerton, Bishop, and Thomas 2006).

Recent critics have pointed out key policy failures, such as inability to adequately compensate the local population's loss of livelihood, failure to understand the complexity of specific cases and excessive focus on markets as the solution to all aspects of conservation (Fletcher et al. 2016; Krüger 2005; Woodward et al. 2014). While most external factors are 
beyond the reach of individual PA initiatives, there are other contributing factors such as community relations, economic strategy and justification for conservation, on which project stakeholders have direct influence through the operational practices they adopt (Table 1).

By 'operational practices', I refer to functions and activities that become routine for a group or organisation. As such, they reflect a compromise between different institutional cultures and values of stakeholders and must be adapted to local conditions often characterised by competing interests and crosscutting power relations. Therefore, those implementing conservation projects must deal with 'resistance' and justify their actions, bring them in line with established institutional guidelines and targets, and at the same time maintain relationships of trust within the community where they work. In the process, they must respond to practical problems, such as crop damage by wildlife, while following established best practices and accommodating both demands within the situational context (Desai 2006).

The present study focuses on Chimanimani National Reserve (ChNR), a little-known PA in a mountainous area with difficult access in central Mozambique. It is part of a broader Transfrontier Conservation Area (TFCA) which includes Chimanimani National Park (NP) in Zimbabwe $\left(155 \mathrm{~km}^{2}\right)$ and the core national reserve $\left(634 \mathrm{~km}^{2}\right)$, with a buffer zone $\left(1,723 \mathrm{~km}^{2}\right)$ in Mozambique, 2,512 $\mathrm{km}^{2}$ in total (Ghiurghi, Dondeyne, and Bannerman 2010). My research question is, to what extent do operational practices adopted by different stakeholders bring forth - or neglect - positive factors and contribute to - or aggravate - PAs' sustainability in relatively unfavourable external conditions? Although based on one case study, the findings are relevant for other PAs struggling with sustainability under similar conditions.

\section{STUDY FRAMEWORK AND CONTEXT}

Mozambique gained independence in 1975 following a decade of armed struggle, and the socialist Frelimo government nationalised all natural resources, including wildlife. Only two years later, the country succumbed to a brutal civil war, during which the PA network was largely abandoned. After the peace accord in 1992 and democratic elections two years later, the need to rehabilitate the PA network was taken up, largely due to external incentives and funding (Soto 2011). The goal of the new wildlife policy from 1996 is "to conserve, utilize and develop forest and wildlife resources to gain social, ecological and economic benefits for present and future generations of Mozambicans" (Ibid., 90). Models for implementing the policy came from pioneering initiatives in neighbouring countries, notably community-based programmes developed in Zimbabwe and Zambia (Virtanen 2003) and South Africa's market-based 'Pilanesberg model' (Child 2011). Based on the new approach, in 1997, the government initiated a large Transfrontier Conservation Area (TFCA) programme funded by the World Bank with additional support from international NGOs and bilateral donors. It envisaged establishing three TFCAs with neighbouring countries (Soto 2011).

However, human resources for nature conservation have remained inadequate in the country, while already-insufficient public funding has declined over the last decades and covers only a small part of the conservation budget. Following the Pilanesberg model, the remaining part is sought from multi- and bilateral donors or international NGOs under various partnership models, where the government usually makes available the natural resources while the partners contribute money, expertise and equipment (Child 2011; Soto 2011). One problem 
with this arrangement is that as the partners usually direct their funding to specific 'promising' PAs, a large number of ecologically and/or economically less-attractive PAs suffer from the transiency or outright absence of funding. Here, the focus is on an operational context (Chimanimani), which is not particularly favourable to upmarket ecotourism or safari hunting, and where revenue opportunities are relatively modest.

While it is generally recognised that effective conservation requires collaboration between the state and local communities (Adams and Hulme 2001), in the context of a resource-poor national government, the Pilanesberg model may elevate the private sector operator to a key role, whilst the state becomes essentially a bureaucratic facilitator, and local communities are relegated to passive beneficiaries (Child 2011; Kiss 2004). Arguably, this is the case in Mozambique's moneyed public-private partnerships, such as the Niassa Game Reserve and Gorongosa National Park, albeit the partnerships may have strengthened the grip of the government in opposition-dominated territory (Diallo 2015; Soto 2011). In the ChNR case similar to other less-attractive and peripheral PAs - the situation is different. Due to perceived low market potential, public and private funding has been scant and sporadic, and finding a committed lead actor has been difficult.

The study is based on (i) the author's interviews and participant observation in the Chimanimani region and Chimoio town in Manica Province, and Maputo when the project was initiated in 1998-2001, and two brief follow-up visits in December 2015 (Chimanimani and Chimoio) and July 2016 (Maputo); (ii) ChNR project documents, progress reports, consultant reports, and academic studies produced in the project context; and (iii) other relevant research literature. I interviewed 24 individuals (many on several occasions) for the study, including ChNR project staff, local government authorities, NGO staff, traditional leaders, members of local management institutions, and other community members. In addition, I conducted participant observation in various field activities and public events organised by the project from 1998-2001. The interviews followed a loose semi-structured agenda. I conducted the interviews in Portuguese, English or local languages (ChiManica or ChiNdau) with the help of an interpreter.

\section{THE CHIMANIMANI TFCA: HISTORY AND ANALYSIS}

The Chimanimani National Park (NP) was created in the border area between Mozambique and Southern Rhodesia (now Zimbabwe) in 1949. Subsequently, the Portuguese administration proclaimed three forest reserves (FRs) on the Mozambican side of the Chimanimani massif, and a feasibility study in the early 1970 s recommended creating a PA covering the area above the 1,000-meter contour (Figure 1). A tar road was being constructed in the area, and a new border post at Rotanda supported optimistic expectations about growing wildlife tourism, which should also bring benefits to local communities (Ghiurghi, Dondeyne, and Bannerman 2010). The proposal was ahead of its time in recommending community participation and demarcation of a buffer zone with a dual function, i.e. to protect the core area and provide benefits for local inhabitants (Singh 2001).

Mozambique's independence in 1975 ended discussions with minority-ruled Rhodesia, and two years later the border region became a battlefield in the civil war (Virtanen 2005). In Chimanimani, the southern part of the massif (including the FRs) eventually fell under the 
control of the Renamo guerrillas, and large areas became 'no man's land', while the government retained control over the main settled areas in the north (Bell 2000; Singh 2001). The war situation contributed to the destruction of the scant social infrastructure (roads and schools) built during the last years of colonialism and cut the local population away from the markets (Schafer and Bell 2002; Serra 2001). Nearly continuous warfare from 1964 to 1992 also caused a significant drop in the wildlife population due to the collapse of law enforcement and subsequent indiscriminate hunting by both the belligerents and the local population (Hatton 1995).

In 1991, as the civil war drew to a close, the first TFCA preparatory mission identified Manica Province as one of three potential areas, and a second mission in 1994 recommended that Chimanimani be included in the programme. The mission further recommended substantial participation of local communities, represented by traditional authorities, in the project, as well as securing their tenure and resource use rights as a prerequisite for effective community-based management. Similar to the earlier proposal, the mission recommended a strict nature protection zone above the 1,000-meter contour, while the buffer zone, where local communities were allowed 'sustainable use' of resources, was to include the area between the Lucite and Mussapa rivers (Hatton 1995). The new PA boundary included a substantial human population, particularly in the lowland triangle near Dombe. It also included two of the FRs but excluded the Moribane FR (Figure 1). However, in a parallel initiative, the Forestry Research Department (CEF) of the National Directorate of Forestry and Wildlife (DNFFB) was starting a community forestry project in the Moribane FR (with funding from the Ford Foundation) to test its new community conservation approach (Serra 2001).

\section{Operating in a hostile political context}

As noted above, the adopted conservation strategy was based on separation of the core conservation area, where anthropogenic activities are limited to non-consumptive use (e.g. ecotourism), from a surrounding buffer zone, where expansive consumptive use, such as deforestation and opening new fields, were restricted. In Mozambique, the operationalisation of community participation was largely based on experience gained from innovative programmes started in Zimbabwe and Zambia in the late 1980s (Virtanen 2003). These emphasised traditional authorities - supplemented by additional representative organs - as the most adequate community representatives, and development of new market-oriented products and livelihoods - notably ecotourism and safari hunting - to replace traditional local livelihoods based on consumptive use of wild natural resources (shifting cultivation, hunting and fishing). Both SPFFB, the provincial arm of DNFFB, which was in charge of the World Bank-funded TFCA project (1997-2003) in Chimanimani, and CEF initially sought to implement their projects based on the received model, albeit without safari hunting (Field observations, Mahate 6.11.1998; Moribane, 5.4.1999).

When the SPFFB and CEF initiated work in the respective project areas in 1996, Renamo, which had transformed into a lawful political party, gained the most local votes in the 1994 national elections (Virtanen 2005) and controlled most of the target area. Consequently, a large part of the local population was suspicious of any government initiative. Project representatives were construed as agents of the ruling party, Frelimo, and many traditional authorities, in particular, were initially hostile toward an increased presence of state authorities in the area (Serra 2001). The first official contacts with traditional leaders and 
other local authorities were made in 1997, when a population survey was initiated, and the first consultancies were implemented by partner NGOs (Interviews, Nhahedzi, 4.12.1998, Chimoio, 25.11.1999). However, as the security situation continued to be problematic in the main TFCA area due to incidences of banditry (Interview, Nhahedzi, 4.12.1998), the SPFFB team started work in the safer and more accessible Tsetserra highland plateau situated to the north of the Chimanimani massif (Ghiurghi, Dondeyne, and Bannerman 2010).

In Moribane, which had been under Renamo control, the CEF staff faced similar hostile conditions (Serra 2001). Many local households sought refuge in the dense forest during the war, and cultivated areas remained small. However, after the peace accord in 1992, there was an influx of settlers to the FR, which offered fertile soils and relatively good access to markets. The rapid expansion of agriculture was accompanied by extensive fires in the forest left dry after a lengthy drought, most of them ignited by people clearing land for farming (Schafer and Bell 2002). To some extent, the practice, that is the invasion of a known PA, reflected conscious resistance to the Frelimo government and its policies similar to 'guerrilla agriculture' practices reported from Uganda (Cavanagh and Benjaminsen 2015).

To overcome the resistance, the CEF team devised a scheme to compensate for the restrictions imposed on the use of forest resources and opening new fields in the buffer zone. New participatory tools, such as participatory rural appraisal, were used to identify development goals and develop a framework for the project together with the population. Based on these tools, the team furnished a grinding mill and identified alternative livelihoods such as apiculture, fish farming and horticulture, which were later introduced by partner NGOs (Interviews, Moribane, 5.4.1999; Serra 2001). However, local protests continued as the CEF team failed to prevent damage to crop fields by elephants. The issue divided the community; those (mostly Renamo veterans) who had settled deep within the FR and suffered the most insisted on shooting the animals, while the chief and those who supported traditional values were against it because the elephants were consecrated to ancestor spirits. The CEF team supported the latter, albeit with different reasons for valuing the elephants, namely wildlife tourism. The dispute finally reached a critical point when a CEF staff member was taken hostage. Subsequent attempts to resolve the issue merely revealed the low value most of the population gave to the benefits offered in compensation (Field observations, Moribane, 5.4.1999; Schafer and Bell 2002; Singh 2001).

\section{Restructuring the project to serve state building}

In 1999, a project workshop was held at a remote motel to address the question of ChNR boundaries, in particular concerning the Moribane FR and Tsetserra plateau. Eventually, both areas were included, Moribane due to its biological and cultural value, and Tsetserra due to the potential environmental impact and economic opportunities of its forest plantations. Otherwise, the agreed boundaries followed roughly those revised by SPFFB (Interviews, Chimoio, 25.1.1999; Figure 1), although exact delimitation was to be done jointly with the traditional authorities (Ghiurghi, Dondeyne, and Bannerman 2010; Singh 2001). In the same year, a foreign consultant was contracted to prepare a management plan for the ChNR. The comprehensive plan (Bell 2000) submitted in 2000 drew attention to the fundamental divergence of values and ambitions between state authorities and local communities. The former focused on conservation of biological and aesthetic values, while the latter expected economic development and protection of sites with spiritual significance. 
The plan (Bell 2000) also noted that the workshop revealed profound confusion about the situation of land and resource tenure displayed by all parties, including government authorities. While acknowledging a certain lack of clarity in the traditional authority structures, it suggested the creation of commercial natural resource management associations headed by traditional authorities. Observing that the current practice of shifting cultivation was highly destructive to the biological and aesthetic values and provided only meagre returns, the plan recommended a strategy based on income from off-farm activities (sale of timber, NTFPs and fish, ecotourism) and use of the income for buying stable foods.

The management plan proposal and its recommendations were never formally endorsed or implemented (Ghiurghi, Dondeyne, and Bannerman 2010). Instead, a new project objective, institutional reinforcement of the SPFFB, was added. This meant that while the consortium now included three state agencies (SPFFB, CEF and the Cultural Patrimony Archive) and five NGOs, SPFFB's role as the coordinating agency was dominant (Interview, Chimoio, 9.1.2001). The project strategy, however, remained obscure to several participants (Interviews, Chimoio, 13.4. \& 27.5.1999). Team meetings were organised in the distant provincial capital (José 2007), and the adopted top-down approach centralised power to the coordinator, a former Provincial Director of the Manica SPFFB, who controlled all resources (Interviews, Nhahedzi, 3.12.1998). Fieldwork was led by a senior SPFFB staff, who was a former military and thus identified with Frelimo by the local population. While the field staff, many of whom were former soldiers, were well prepared for living in field conditions, they had little if any experience from participatory practices or socio-economic surveys. Consequently, the approach tended to be authoritative rather than empowering, and in the politically sensitive context, agreeing on joint objectives turned out to be arduous and sometimes impossible (Interviews, Chimoio, 8.11.2001; cf. José 2007; Schafer and Bell 2002).

Due to poor communication between different institutions and hierarchical administrative culture, progress was slow and often frustrating (Interviews, Chimoio, 10.11.1998 \& 12.11.2001). The team made several attempts to mobilise the communities to establish the resource management institutions recommended by the received best practice guidelines, and consultancies were implemented by partner NGOs to develop alternative livelihoods, such as irrigated agriculture and apiculture. Some rustic trails, a radio link and campsites were also opened (Interviews, Chimoio, 13.4.1999 \& 18.8.2000). However, in 2000, a cyclone destructed approximately 80 per cent of the infrastructure and large areas of the plantations in Tsetserra (Interviews, Chimoio, 9.11.\& 12.11.2001).

When the World Bank funds were exhausted by the end of 2002, concrete benefits to communities were marginal. A large part of the funds had been used for salaries, travel and modern equipment (e.g. four-wheel drive vehicle and VHF radio) for the project consortium and SPFFB senior staff in particular (Interview, Chimoio, 8.11.2001). The few classrooms and ambulant health services were still available, along with some rebuilt tracks and bridges maintained by community members. The honey and mushroom projects were terminated due to problems in processing and lack of reliable markets; fish farming had minimal success, and sale of timber by the community was not permitted. No proper market studies were done; rather markets for new products were presumed to exist (Singh 2001; José 2007). Investment 
in campsites and staff for cultural and ecotourism projects took place with the belief that tourists would come automatically when facilities existed. This turned out to be false; government-owned campsites and guides - who were supposed to get their income directly from the clients - remained idle, the former falling into disrepair and the latter leaving (Interviews, Ndzou Camp, 17-18.12.2015).

The community consultation process focused on selling the project to the communities (Field observations, Mahate, 6.11.1998; José 2007; Singh 2001). Local committees were used to convey decisions made by project leaders to the communities (Schafer and Bell 2002), and many local inhabitants perceived the project as an attempt by Frelimo to gain a foothold in an opposition stronghold (Serra 2001; cf. Diallo 2015). In practice, the project caused - or strengthened existing - cleavages within the communities by creating tense relationships between traditional authorities, whom it bolstered in part, and the new democratic and gender-balanced management committees, on which the project staff insisted (Singh 2001; Schafer and Bell 2002).

In 2003, the PA boundaries were finally defined by a decree, which officially created the NR. The delimitation appears to have been done on drawing board. In the core zone, the borders were straight lines linking selected coordinates, which did not follow natural features or even traditional community boundaries (Figure 1). The core zone also incorporated densely populated areas (Nhabawa and Ferreira) as well as extensive areas with no specific conservation value. The formal delimitation of community lands (a category of communal tenure established in the 1997 Land Law) in five communities within the ChNR was finalised in 2002 (Ghiurghi, Dondeyne, and Bannerman 2010). While the land titles tied the local communities and their natural resources more closely to the government-led system, it was one of the few lasting results of the project, which has - arguably - strengthened community ownership (Dondeyne, Kaarhus, and Allison 2012; José 2007). Interestingly, in the same year the reserve was declared, the district agricultural service authorised local families to open farms in the Moribane FR, where large areas had been cleared for growing banana. The decision was justified by the termination of the TFCA project in Chimanimani, the failure of its income generating activities and lack of other employment opportunities (José 2007).

\section{Dependence on donor support and lack of shared objectives}

The project's tailing off in 2003, and related termination of external support for conservation and development activities, led to a rapid increase of deforestation for agricultural expansion. This was expedited by new agricultural projects and logging concessions granted in the buffer zone by other government authorities without the ChNR administration's knowledge (Ghiurghi, Dondeyne, and Bannerman 2010; cf. Krüger 2005).

Illegal artisanal mining caused another setback. The summits of the Chimanimani massif are rich in gold, and artisanal mining is a traditional activity in areas adjacent to the PA. In the early 2000s, as the economic crisis in Zimbabwe worsened, there was an influx of illegal miners to the TFCA. Artisanal gold extraction takes place along streams, causing turbidity, siltation and pollution from mercury, as well as the destruction of riparian vegetation. In early 2006, the number of illegal miners in the ChNR was estimated at 10,000. Mozambican security forces attempted to evict the intruders and managed to reduce the number of miners to approximately 2,000 , but they were dispersed even more widely throughout the core zone (Ndunguru, Dondeyne, and Mulaboa 2006). While the traditional authorities were mostly 
hostile toward alien miners, they did not object to the activity itself - unless it took place in or too close to sacred locations (Kachena and Spiegel 2018).

At the same time, tourism in the TFCA declined drastically. From 2005 to 2008, the average number of tourists entering the ChNR was approximately 80 per year, and due to the economic and political situation in the country, annual tourist numbers in the Zimbabwean NP fell from approximately 10,000 in 2000 to 600 in 2008 (Ghiurghi, Dondeyne, and Bannerman 2010). By then, the only remaining tourist facilities in the ChNR were three campsites in a precarious condition. Existing access roads and bridges were rudimentary at best, and the few facilities available for guides and rangers were rapidly deteriorating due to lack of income and funds for maintenance (Interviews, Ndzou Camp, 17-18.12.2015; Ghiurghi, Dondeyne, and Bannerman 2010). Lack of sustainability of the adopted state-led operational practices resulted in a vicious cycle as external resources petered out, while the transfrontier aspect of the PA lost its economic rationale.

\section{Pursuing market sustainability through private sector partnerships}

In 2008, consultants from an Italian company, with support from the ChNR staff, prepared a new management plan. . The new plan (Ghiurghi, Dondeyne, and Bannerman 2010), which was officially endorsed in 2011, was based largely on the draft from 2000. Based on the 1996 Wildlife Policy, the plan's objectives are reflected in its operational practices, of which five refer to preserving natural and cultural values, two to improving living standards of local people and their active involvement in PA management, and one to evidence-based management. Concrete changes include adjusting the core zone's boundaries to follow natural features and exclude populated areas (Nhabawa and Ferreira) while including ecologically important areas previously left out (Figure 1). In the buffer zone, land delimitation was to be concluded in the whole area, and subsequently, communal land use plans (including community conservation areas) prepared. The new management board would also include strong representation from local communities in the form of traditional authorities and natural resource management committees in addition to local and state administration, NGOs and the private sector. Community institutions would also gradually assume law enforcement tasks, such as poaching control and fire management in the buffer zone. However, the plan does not indicate the source of funding for these activities.

Key benefits for communities were again expected from expanding ecotourism, which would require improvement of infrastructure, such as new access roads with bridges and proper entrance gates, as well as facilities for the PA staff. While these would depend on public funding, development of tourism infrastructure (including the two government campsites) should be based on joint ventures between the private sector and local communities, who now hold tenure rights in the buffer zone. Aside from already familiar alternative livelihoods, new benefit-related practices identified in the plan include carbon trading and conservation agriculture (improved soil conservation, irrigation and horticultural production). All require creating commercial linkages between the communities and the private sector to secure reliable markets, something the previous projects failed to accomplish (Ghiurghi, Dondeyne, and Bannerman 2010).

The World Bank provided some funding in the context of a broader Conservation Areas and Tourism Development project (2010-2012), but in line with the bank's practices, the main role was given to private consultants. The focus was on capacity building and partnerships in 
the form of community-private sector joint ventures. It followed market-based operational practices, such as establishing a specific enterprise fund, elaboration of management and business plans and other support for creating community enterprises. In addition, activities were initiated to establish and implement management plans for key areas and strengthen the participatory process (PI Consult 2012). To some extent, the activities were justified by the evident shortcomings of previous state-led operational practices in terms of market sustainability and power-sharing (cf. Krüger 2005), but the match of the standard neo-liberal, market-based practices with the concrete needs of the local population remained weak. The limited duration of funding and reliance on external expertise eroded the project's sustainability, and, at least in Chimanimani, there was only scarce follow-up on the activities. This was a crucial failure, as gaps in support often result in a resurgence of unsustainable local practices, increase in wild fires and so forth - as observed in Moribane (Interview, Ndzou Camp, 17.12.2015; cf. Adams and Hulme 2001).

\section{Reducing the scale while moving beyond projects}

More concrete results with the bank's funding were obtained by MICAIA, a network of organisations established in 2007, which consists of Micaia UK, a British charity working in Mozambique, Micaia Foundation based in Chimoio, and Eco-Micaia, a social enterprise working with ecotourism and food products. While the geographical scale of MICAIA's activities in Chimanimani remains limited, it has focused on strengthening three aspects of the new plan, which they considered crucial for the sustainability of the conservation efforts, namely sustainability of the benefits, genuine power sharing, and building a shared value base (including non-monetary aspects) for conservation.

MICAIA has striven to move away from short-term 'income generating projects', which tend to be financially unsustainable, toward long-term support to viable business based on realistic market analysis (Interviews, Ndzou Camp, 17.12.2015 and Maputo, 28.7.2016). It is partowner of a cooperative honey company together with approximately 5,000 beekeepers, including a large number from Chimanimani, who own one third of the shares. In honey production MICAIA works on the full value chain from producer to markets, which are now nation-wide in Mozambique, while openings to lucrative global 'fair trade' and 'organic' markets are pursued. This has required changes in the chain, such as transfer of processing from the producers to the cooperative's factory in Chimoio to fulfil the hygiene requirements of certification (Interviews, Chimoio, 17.12.2015). Honey production is currently the main economic activity supported in the Chimanimani area by MICAIA, although the staff has also experienced with other forest products, such as dried wild fruits and chili pepper. However, despite several years of operation, the cooperative is still struggling with economic sustainability (Interviews, Ndzou Camp, 17.12.2015 and Maputo, 28.7.2016).

The second main activity supported by MICAIA is ecotourism, where the activities have focused on making an ecotourism facility, which opened in the Moribane FR in 2010, economically viable. The camp is a joint venture with the local community association, which participates in its management, and part of the initial investment came from the World Bank project. The other camps, a government owned and a private one situated further away from the main roads, had been abandoned as there were very few tourists due to political insecurity in the central region and the economic collapse in Zimbabwe. Even the Moribane camp's viability, which suffered from access problems due to roadworks in 2013-2015 on the 
main road passing by the camp, was saved only by demand from the same roadwork crews (Interviews, Ndzou Camp, 17.12.2015). Again, financial sustainability in the difficult local ecotourism markets remains precarious despite MICAIA's active promotion efforts.

MICAIA has also created functional partnerships with both national and European research institutions, which have undertaken projects to assess the potential for carbon trading under the REDD+ framework, and hence increase local benefits from conservation. The collaborations also include biodiversity surveys and joint planning for sustainable use of natural resources, including local monitoring systems supported by an international NGO (Interview, Ndzou Camp, 17.12.2015). A key objective has been to build a joint conservation oriented value base with the local communities, but it remains to be seen if the envisaged 'payment for ecosystem services' (PES) initiatives prove to be viable in the changing economic context of REDD+ (Fletcher et al. 2016).

While it facilitates access to markets, improved road connection is not only a blessing, as it has augmented the influx of immigrants from other areas and clearing of new lands for agriculture. Although the traditional chief of Moribane claimed that he does not accept new immigrants to his area (Interview, M'Punga, 18.12.2015), this has apparently not prevented the influx, which has caused friction within the community (Kachena and Spiegel 2018; cf. Virtanen 2003). The expansion of low value cash crop (mainly maize and banana) cultivation has been a problem in the Moribane area ever since the early 1990s, and it continues to be the main threat to forest conservation today. MICAIA has attempted to combat the agricultural expansion by promoting conservation agriculture, high-value crops and intensive cultivation techniques, but income from the alternative livelihoods is often invested in clearing more fields for the traditional cash crops (Interviews, Ndzou Camp, 17.12.2015; cf. Kiss 2004). Elephants also still represent a threat to agriculture, although people have mostly moved off from the protected dense forest. MICAIA and the communities disagree over the solution: the latter have requested building an electric fence to protect the homesteads and fields, but MICAIA considers it unviable. Instead they have started building a chain of beehives at the forest edge to fend off the elephants, which avoid bees. The chain - still only partly finished - is also expected to separate the cultivated area from the new community conservation zone (Interviews, Ndzou Camp, 17.12.2015 and M'Punga, 18.12.2015). Although some progress has been made toward a shared value base, several controversial issues remain.

\section{CONCLUSIONS}

All the key planning documents of the Chimanimani TFCA reflect a strong commitment to the operational practices of community participation and market-based development, which had become the dominant conservation paradigm when the PA was initiated. However, they all proved to be over-optimistic about the ability of the diverse stakeholders to translate the recommended 'best practices' - imported through the neighbouring countries - into sustainable activities under the unfavourable external conditions of Chimanimani.

After the crucial first years were spent in introducing the new conservation ideology and developing local implementation practices in a hostile and polarised political context, the focus of the project changed radically. Instead of community- or market-based, the dominant operational practice adopted was state-led, with only scant attention given to market 
sustainability or power sharing with local communities. While the project faced adverse conditions in the form of extreme climatic events and the shrinkage of regional tourism due to political and economic turmoil, the weak sustainability of the first phase was mainly caused by internal factors. The project depended on short-term donor funding, which was largely spent on the state-led implementation staff, and when it ended the project was forced to close, leaving very few durable benefits to local communities. As power sharing with the local communities remained nominal, ownership of and commitment to the imported conservation ideology were low among the local population, which remained divided. This rendered the whole conservation initiative vulnerable to external pressure.

The external threats were realised in the form of increasing deforestation for agriculture in the buffer zone, and invasion of the core zone by illegal miners. At the same time, the few remaining facilities built by the project deteriorated and were mostly abandoned. A new management plan was prepared in 2010, and the project received some funding from the World Bank to improve market sustainability, notably community-private sector joint ventures and related management plans. However, the activities were mostly assigned to external consultants, and the proposed plans suffered from weak community participation and lack of follow-up. The main exception to this was funding directed to MICAIA, which had long practical experience in working with local communities and challenging markets. Their long-term approach seeks to adapt market-based operational practices to local context, complemented with effective power sharing with the communities. While the alternative livelihoods and community-based ecotourism activities they have introduced have also faced problems, active power sharing and emphasis on sustainable markets have yielded relatively promising, albeit still tenuous results in the Moribane area despite continuing political and economic turbulence.

Expanding the benefits of the developed operational practices to the entire PA remains a challenge under the current external conditions, and it is unlikely to be sustainable without continuing support from the government and/or external donors. While the private sector can bring capital and business and marketing know-how, which complements the local resources brought by the community partner, the public sector should be prepared to take responsibility of the costs involved in providing public goods, such as road infrastructure and social services in the buffer zone, as well as conservation activities inside the core area (cf. Kiss 2004). This is, however, difficult to achieve unless the stakeholders can agree on a common value base for conservation, which appears to be the most challenging task.

Previous meta-analysis studies have shown that reliance on income from ecotourism or PES initiatives can provide a sustainable basis for conservation in PAs with the natural resources and external conditions for more lucrative non-consumptive sources of income than the current consumptive sources (Fletcher et al. 2016; Kiss 2004; Krüger 2005). By contrast, in PAs like the ChNR spotting animals typically requires onerous physical effort and long treks in the wild, which tends to dissuade the upmarket clients. Such PAs are also somewhat distant from standard tourist routes and often suffer from difficulty of access and political instability (Wells 1992). As the current markets for PES remain tenuous (Fletcher et al. 2016), ecotourism provides the main incentive for state investment in PAs, which makes substantial public investment in the less attractive cases unlikely. The findings of the Chimanimani case study show that in such unfavourable conditions it is essential to build 
strong mechanisms for active and equal community participation based on both realistic expectations of benefits and jointly defined conservation goals - including the evasive nonmonetary values. As market sustainability is crucial in the context of tenuous public funding, the activities should preferably start from small-scale, locally operated joint ventures, which can be gradually expanded and/or replicated to new areas (cf. Kiss 2004; Krüger 2005). But while exclusive dependence on public contributions may be unadvisable, the state continues to have a strong role in other key areas of conservation, such as infrastructure, legislation, law enforcement and policy formulation.

Table 1. Factors contributing to sustainability of PA initiatives

\begin{tabular}{|l|l|l|}
\hline Contributing factor & Positive & Negative \\
\hline Sustainability of market & Sustainable & Not sustainable \\
\hline Local costs/benefits & Benefits outweigh costs & Costs outweigh benefits \\
\hline Donor investment & Long-term & Short-term \\
\hline Conservation ideology & Adopted by all parties & Not/partially adopted \\
\hline Meeting expectations & Benefits as promised & Promises not delivered \\
\hline Power sharing & Genuine power sharing & Token power sharing \\
\hline Non-monetary values & Shared with community & Not shared with community \\
\hline
\end{tabular}

Adapted from Adams and Hulme 2001, 195. 


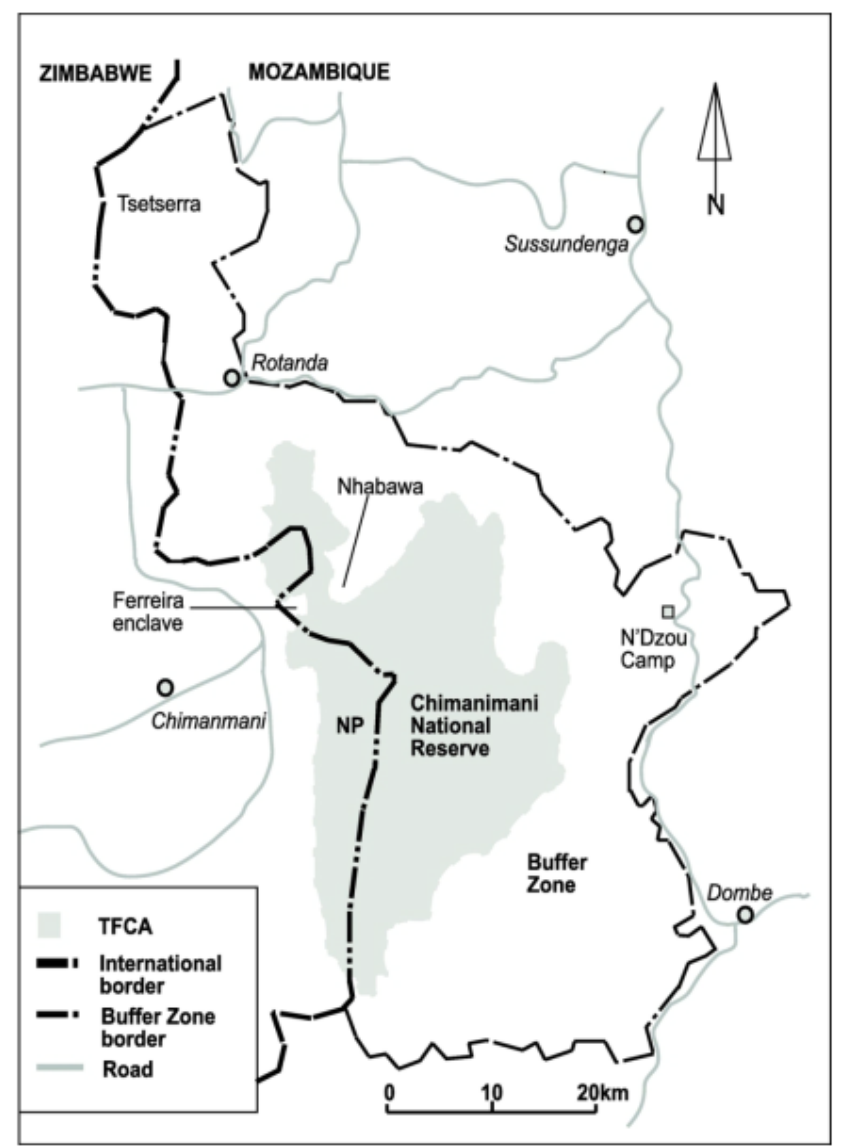

Figure 1. Chimanimani TFCA is situated between $32.8^{\circ} \mathrm{E}-33.4^{\circ} \mathrm{E}$, and $19.3^{\circ} \mathrm{S}-20.0^{\circ} \mathrm{S}$. It consists of a mountain massif rising out from tropical plains at about 200 meters above sea level to temperate mountain ranges and plateaux above 1,000 meters, while the highest peak reaches 2436 meters. (Map based on Ghiurghi, Dondeyne, and Bannerman 2010.)

$110 \times 154 \mathrm{~mm}(300 \times 300 \mathrm{DPI})$ 


\section{References}

Adams, William, and David Hulme. 2001b. "If community conservation is the answer in Africa, what is the question?" Oryx 35(3): 193-200.

Bell, Richard. 2000. Proposed Nakaedo Biosphere Reserve - Chimanimani Transfrontier Conservation Area: Management Plan. Maputo: DNFFB.

Cavanagh, Connor, and Tor Benjaminsen. 2015. "Guerrilla agriculture? A biopolitical guide to illicit cultivation within an IUCN Category II protected area." The Journal of Peasant Studies 42: 725-745.

Child, Brian. 2011. "Recent innovations in conservation." In Evolution and innovation in wildlife conservation, edited by Helen Suich and Brian Child, 277-287. London: Earthscan.

Desai, Bina. 2006. "Inside out: Rationalizing practices and representations in agricultural development projects." In Development brokers and translators: The ethnography of aid and agencies, edited by David Lewis and David Mosse, 173-193. Bloomfield: Kumarian Press.

Diallo, Rozenn. 2015. "Conservation philanthropy and the shadow of state power in Gorongosa National Park, Mozambique.” Conservation and Society 13(2): 119-128.

Dondeyne, Stefaan, Randi Kaarhus, and Gaia Allison. 2012. "Nature conservation, rural development and ecotourism in Central Mozambique: Which space do communities get?" In Making sense of place: Multidisciplinary perspectives, edited by Ian Convery, Gerald Corsane, and Peter Davis, 291-301. Woodbridge: Bydell Press.

Emerton, Lucy, Joshua Bishop, and Lee Thomas. 2006. Sustainable financing of protected areas: A global review of challenges and options. Gland: IUCN.

Fletcher, Robert, Wolfram Dressler, Bram Büscher, and Z.achary Anderson. 2016. "Questioning REDD+ and the future of market-based conservation." Conservation Biology 30(3): 673-675.

Ghiurghi, Andrea, Stefaan Dondeyne, and James Bannerman. 2010. Chimanimani National Reserve management plan, Vol. I-II. Rome: Agriconsulting.

Hatton, John. 1995. Status quo assessment of the Chimanimani Transfrontier Conservation Area: Report to DNFFB. Harare: IUCN-ROSA.

José, Paulo. 2007. "Strategies for sustainable rural development in Mozambique: A case study of the Chimanimani Transfrontier Conservation Area project." MA diss., University of the Witwatersrand.

Kachena, Lameck, and Samuel Spiegel. 2018. "Borderland migration, mining and transfrontier conservation: questions of belonging along the Zimbabwe-Mozambique border." GeoJournal (2018). https://doi.org/10.1007/s10708-018-9905-0.

Kiss, Agnes. 2004. "Is community-based ecotourism a good use of biodiversity conservation funds?" Trends in Ecology and Evolution 19(5): 232-237.

Krüger, Oliver. 2005. "The role of ecotourism in conservation: panacea or Pandora's box?" Biodiversity and Conservation 14: 579-600.

Ndunguru, Eduardo, Stefaan Dondeyne, and Jorge Mulaboa. 2006. "Illegal gold mining in the Chimanimani National Reserve: environmental and socio-economic assessment." Accessed June 102015. 
http://www.eisourcebook.org/cms/Feb\%202013/Illegal\%20gold $\% 20$ mining $\% 20 \mathrm{in} \% 20$ the $\% 2$ 0Chimanimani\%20National\%20Reserve.pdf.

PI Consult. 2012. "Implementation of community development strategy in Chimanimani TFCA.” Accessed October 12 2014. http://www.ip-consult.de/projects/implementation-ofcommunity-development-strategy-in-chimanimani-tfca-in-the-framework-of-the-tfcatd.

Kentän koodi muuttunut

Schafer, Jessica, and Richard Bell. 2002. "The state and community-based natural resource management: the case of the Moribane forest reserve, Mozambique." Journal of Southern African Studies 28: 401-420.

Serra, Antonio. 2001. Legtimacy of local institutions for natural resource management: The case of M'Punga, Mozambique. Brighton: University of Sussex, Marena Working Paper No. 3.

Singh, Jaidev. 2001. "State-making and community-based natural resource management: Cases of the Vhimba CAMPFIRE Project (Zimbabwe) and the Chimanimani Transfrontier Conservation Area (Mozambique)." PhD diss., University of Washington.

Soto, Bartolomeu. 2011. "Protected areas in Mozambique." In Evolution and innovation in wildlife conservation, edited by Helen Suich, and Brian Child, 85-100. London: Earthscan.

Virtanen, Pekka. 2003. "Local management of global values: Community-based wildlife management in Zimbabwe and Zambia.” Society and Natural Resources 16: 179-190.

Virtanen, Pekka. 2005. "Community-based natural resource management in Mozambique: A critical review of the concept's applicability at local level." Sustainable Development 13: 112 .

Wells, Michael. 1992. "Biodiversity conservation, affluence and poverty: Mismatched costs and benefits and efforts to remedy them." Ambio 21(3): 237-243.

Woodward, Richard, Amanda Stronza, Elizabeth Shapiro-Garza, and Lee Fitzgerald. 2014. "Market-based conservation: Aligning static theory with dynamic systems." Natural Resources Forum 38: 235-247. 